\title{
HELMINTH INFRACOMMUNITIES OF GALLOTIA CAESARIS CAESARIS AND GALLOTIA CAESARIS GOMERAE (SAURIA: LACERTIDAE) FROM THE CANARY ISLANDS (EASTERN ATLANTIC)
}

\author{
Juan E. Martin and Vicente Roca* \\ Departament de Zoologia (Parasitologia Animal), Facultat de Ciències Biològiques, Universitat de Valencia, Dr. Moliner 50, 46100 Burjassot, \\ València, Spain.e-mail: vicente.roca@uv.es
}

\begin{abstract}
A survey of gastrointestinal helminth communities of Gallotia caesaris caesaris (Lehrs, 1914) and G. c. gomerae (Boettger and Müller, 1914), from the islands of El Hierro and La Gomera, respectively, in the Canary Archipelago, Spain, was conducted to determine the prevalence, intensity, and diversity of intestinal parasites of these lacertid lizards. Larval forms of cestodes, nematodes, and acanthocephalans were found in the body cavity of G. c. caesaris; this lizard is the intermediate or paratenic host in the life cycle of these helminths. Pharyngodonid nematodes were the most common intestinal helminths in both hosts, 4 of them being Gallotia spp. specialists. Helminth infracommunities of both hosts were depauperate and isolationist, according to the low values of helminth diversity.
\end{abstract}

The Canarian Archipelago, located off the northwest coast of Africa, at $27^{\circ} 37^{\prime}-29^{\circ} 24^{\prime} \mathrm{N}, 13^{\circ} 37^{\prime}-8^{\circ} 10^{\prime} \mathrm{W}$, comprises 7 main islands and a number of peripheral islets. Lacertids living in this archipelago belong to endemic species Gallotia (Arnold, 1973). El Hierro and La Gomera islands are inhabited by different subspecies of Gallotia caesaris: G. c. caesaris on El Hierro and G. c. gomerae on La Gomera (Thorpe et al., 1993; Barahona et al., 2000; Mateo and García-Márquez, 2002).

Although several recent ecological studies are available on helminth communities of reptiles (Dobson and Pacala, 1992; Dobson, Pacala, Rougharden et al., 1992; Goldberg and Bursey, 1998; Goldberg et al., 1999), there is a paucity of data on the structure of the helminth communities of European reptiles (Roca and Hornero, 1994; Roca, 1995; Sanchis et al., 2000). For the Canary Islands, data are available for 2 subspecies of G. galloti living on the islands of Tenerife and La Palma (V. Roca, unpubl.).

In this article, we analyze the prevalence, intensity, and diversity of helminths from G. c. caesaris and G. c. gomerae, specifically addressing the following issues: (1) characterization of the patterns of helminth community richness and diversity, (2) evaluation of the exchange of helminths between both lizard subspecies, (3) characterization of the helminths parasitizing both hosts as either specialists or generalists, and (4) comparison of the helminth fauna of $G$. caesaris with that of other continental and insular lacertid hosts.

\section{MATERIALS AND METHODS}

El Hierro is a volcanic island $\left(269 \mathrm{~km}^{2}\right.$; maximum elevation of 1,500 m) with a peripheral position in the Canarian Archipelago (Fig. 1). The island is microclimatically and ecologically heterogeneous because of the interaction of its surface relief with wet air masses carried by trade winds from the northeast and the presence of ancient volcanic soils that provide multiple opportunities for plant colonization (García-Márquez, López-Jurado et al., 1999). In all, 318 lizards were caught in several localities from this island (Fig. 1) during March-November 1995.

La Gomera is also a volcanic island $\left(378 \mathrm{~km}^{2} ; 800 \mathrm{~m}\right)$. As for El Hierro, the combination of geomorphological features and climate has given rise to numerous ecological habitats and a diverse flora and fauna Twenty-one lizards were caught in San Antonio (Fig. 1) in July 1995.

All lizards captured were killed with an overdose of chloroform. The body cavity, digestive tract, heart, lungs, and liver were removed,

Received 6 February 2003; revised 6 October 2003; accepted 6 October 2003

* To whom correspondence should be addressed. opened, and placed in Ringer's solution for examination. Helminths were removed, washed in distilled water, fixed, and mounted according to standard techniques. Parasites were identified, when possible, to species, and the number and location of individuals of each species were recorded.

The use of descriptive ecological terms follows Bush et al. (1997). Brillouin's index was used for calculating diversity according to Magurran (1988)

\section{RESULTS}

A total of 12 helminth species was found (10 Nematoda, 1 Cestoda, and 1 Acanthocephala). Nine of the nematode species were recorded as adults and 1 as a larval stage. Only larval specimens of Cestoda and Acanthocephala were found.

Mesocestoides sp., Centrorhynchus sp., and Spirurida gen. sp. (all as larvae) were located in the body cavity, whereas the remaining nematodes were found in the digestive tract. The total number of parasite species and the infection parameters for each host subspecies are shown in Tables I, II. The overall prevalence of infection in G. c. caesaris from El Hierro was $85.2 \%$, whereas it was $81.0 \%$ in G. c. gomerae from La Gomera (Table III).

Intestinal infracommunities of both host subspecies comprised mainly pharyngodonid nematodes. Prevalences of these nematodes were less than $30 \%$ for 12 of the 17 helminth-host species pairs. Only 2 species infected more than $50 \%$ of the host populations. The 3 species that used lizards as intermediate hosts (Mesocestoides sp., Centrorhynchus sp., and Spirurida gen. sp.) each infected less than $3 \%$ of their host populations.

Table IV shows the diversity parameters for helminth infracommunities in both hosts. Helminth richness and proportion of lizards with 0 or 1 helminth species were similar in both hosts. The number of helminths per host (abundance) and Brillouin's index (diversity) were lower in G. c. caesaris than in G. c. gomerae.

\section{DISCUSSION}

The most common nematodes in the infracommunities of $G$. c. caesaris and G. c. gomerae are members of the Pharyngodonidae, of which Thelandros galloti, T. filiformis, T. tinerfensis, Spauligodon atlanticus, and Alaeuris numidica canariensis are endemic species or subspecies on the Canary Islands. Thelandros galloti, $T$. filiformis, $S$. atlanticus, and A. n. canariensis can be considered as Gallotia specialists (sensu Edwards and 


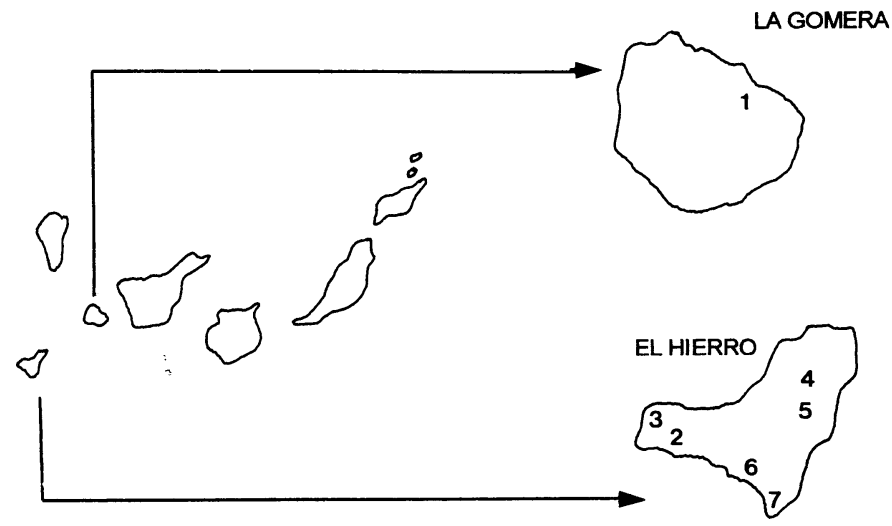

FIGURE 1. Location of El Hierro and La Gomera islands in the Canarian Archipelago. Prospected localities for lizards in both islands: 1. San Antonio; 2. Los Llanillos; 3. La Dehesa; 4. Nisdafe; 5. San Andrés; 6. El Risco; and 7. El Gaterón.

Bush [1989], but also see Roca and Hornero [1994]) but not for other European lizards. Thelandros tinerfensis is not a Gallotia specialist because it was also found in the scincid Chalcides viridanus (Solera-Puertas et al., 1988). The remaining helminths parasitizing both hosts appear to be generalist species.

The presence of larval forms of helminths infecting $G$. c . caesaris suggests that this lizard may be an intermediate or paratenic host in the life cycles of Mesocestoides spp., Centrorhynchus sp., and Spirurida gen. sp. For species of Mesocestoides, several reptile species have been identified as paratenic hosts (Soldatova, 1944; Mankau and Widmer, 1977), including some insular and continental European lacertid lizards (Roca et al., 1986; Roca and Hornero, 1991) and also geckoes from the Canary Islands (Roca et al., 1987). Feral cats, and birds of prey, have been identified as definitive hosts for species of Mesocestoides (Voge, 1955; Roca et al., 1987), and may be definitive hosts for Mesocestoides sp. found in G. c. caesaris, because feral cats are important predators of this lacertid lizard on El Hierro island (García-Márquez, Caetano et al., 1999). According to Poinar (1983), the life cycles of most species of Spirurida use insects or other invertebrates as first intermediate hosts. In addition, larval forms of Spirurida have been found in lacertid lizards (Roca et al., 1986; Roca and Hornero, 1994). In fact, Roca and Hornero (1991) suggested that lizards probably are paratenic hosts in the life cycle of these larval forms, with lizard-eating birds as their definitive hosts. Thus, because G. c. caesaris harbors larvae of Spirurida, it may be its paratenic host. Birds of prey (Falco tinnunculus) (García-Márquez, López-Jurado et al., 1999) would be definitive hosts on El Hierro Island. Because many reptiles are intermediate hosts in the life cycles of acanthocephalans (Goldberg et al., 1996), it is not surprising to find larvae of these parasites in lizards from the Canary Islands. Larvae of Centrorhynchus sp. have also been found in lizards from the Balaearic Islands (Roca and Hornero, 1991; Hornero and Roca, 1992) and geckoes from the Canary Islands (Roca, Martin, and Carbonell, 1999); birds of prey may also serve as definitive hosts for these larval forms (Yamaguti, 1963; Hornero and Roca, 1992).

Although samples of hosts from the 2 islands were heterogeneous with respect to sample sizes and sampling times, we suggest that the helminth fauna of G. c. caesaris and G. c. gomerae is very similar. The most common helminths (T. galloti, T. filiformis, T. tinerfensis, and $S$. atlanticus) were present on both islands, as has been found in other similar archipelagos (Dobson, Pacala, Rougharden et al., 1992; Roca and Hornero, 1994).

One of the effects of the insularity on the helminth fauna of some hosts, noted by Mas-Coma and Feliu (1984) and MasComa et al. (1987), is a higher prevalence of infection in hosts as compared with hosts living on continents. In general, when hosts occur at high densities (as in the case of lizards on the Canary Islands), they show elevated prevalences. The insular physiography may be of great importance in this context because it determines the behavior of free-living species regarding

TABLE I. Infection parameters of the helminths parasitizing Gallotia caesaris caesaris from El Hierro.

\begin{tabular}{|c|c|c|c|c|c|}
\hline \multirow[b]{2}{*}{ Helminth species } & \multirow[b]{2}{*}{ Site of infection } & \multirow[b]{2}{*}{ Prevalence* } & \multicolumn{2}{|c|}{ Intensity of infection } & \multirow{2}{*}{$\begin{array}{c}\text { Mean } \\
\text { abundance }\end{array}$} \\
\hline & & & Range & $\bar{x}$ & \\
\hline \multicolumn{6}{|l|}{ Cestoda } \\
\hline Mesocestoides sp. & Body cavity & $1(0.3)$ & - & - & - \\
\hline \multicolumn{6}{|l|}{ Nematoda } \\
\hline Thelandros galloti & Cecum & $159(50.0)$ & $1-108$ & $14.6 \pm 17.5$ & $7.3 \pm 14.3$ \\
\hline T. filiformis & Cecum & $56(17.6)$ & $1-348$ & $33.1 \pm 66.7$ & $5.8 \pm 28.8$ \\
\hline T. tinerfensis & Cecum & $6(1.9)$ & $6-27$ & $18.0 \pm 7.3$ & $0.3 \pm 2.7$ \\
\hline Parapharyngodon micipsae & Cecum & $49(15.4)$ & $1-97$ & $8.4 \pm 14.5$ & $1.3 \pm 4.3$ \\
\hline Spauligodon atlanticus & Cecum & $113(35.5)$ & $1-186$ & $26.1 \pm 32.7$ & $9.3 \pm 17.8$ \\
\hline Alaeuris numidica canariensis & Cecum & $2(0.6)$ & $3-15$ & $9.0 \pm 12.6$ & $0.1 \pm 4.1$ \\
\hline Tachygonetria dentata & Cecum & $1(0.3)$ & - & - & - \\
\hline T. macrolaimus & Cecum & $1(0.3)$ & - & - & - \\
\hline Skrjabinelazia pyrenaica & Digestive tract & $42(13.2)$ & $1-10$ & $1.7 \pm 1.6$ & $0.2 \pm 3.5$ \\
\hline Spirurida gen. sp. & Body cavity & $8(2.5)$ & $1-6$ & $2.0 \pm 1.8$ & $0.1 \pm 2.1$ \\
\hline \multicolumn{6}{|l|}{ Acanthocephala } \\
\hline Centrorhynchus sp. & Body cavity & $1(0.3)$ & - & - & - \\
\hline
\end{tabular}

* Number of hosts parasitized divided by the number of hosts sampled $(\mathrm{n}=318)$. Values in parentheses are in percentages. 
TABLE II. Infection parameters of the helminths parasitizing Gallotia caesaris gomerae from La Gomera.

\begin{tabular}{|c|c|c|c|c|c|}
\hline Helminth species & Site of infection & Prevalence* & \multicolumn{2}{|c|}{ Intensity of infection } & $\begin{array}{c}\text { Mean } \\
\text { abundance }\end{array}$ \\
\hline Thelandros galloti & Cecum & $8(38.1)$ & $3-88$ & $29.5 \pm 28.8$ & $11.2 \pm 22.5$ \\
\hline T. filiformis & Cecum & $7(33.3)$ & $2-89$ & $30.1 \pm 31.1$ & $10.1 \pm 22.4$ \\
\hline T. tinerfensis & Cecum & $2(9.5)$ & $16-31$ & $23.5 \pm 10.6$ & $2.2 \pm 7.5$ \\
\hline
\end{tabular}

* Number of hosts parasitized divided by the number of hosts sampled $(n=21)$. Values in parentheses are in percentages.

feeding, cohabitation with other species, and choice of biotopes different from those that are usual on the mainland. Roca (1995) noted that this effect should not be generalized in lizards, although in his study, prevalences of infection in insular lizards were usually higher than in continental hosts (Table III). Both G. c. caesaris and G. c. gomerae show higher prevalences than other continental Mediterranean lacertid lizards (Roca, 1995), which is probably due to greater host population densities and island physiography (Mas-Coma and Feliu, 1984). But they also show higher prevalences than other insular lizards (Roca, 1995) (Table III). This may be explained in 2 nonexclusive ways. First, the increase in prevalence is more marked on oceanic islands, e.g., Canary Islands, than on continental or "land bridge" islands, e.g., Balearic and other Mediterranean islands (see Roca, 1995). Second, the tendency toward herbivory in saurians (higher in canarian lizards; see Roca, 1999) will increase their prevalence of infection, mainly in pharyngodonid nematodes, as noted by Roca (1999).

The low values of helminth richness and abundance (Table IV) indicate that many members of the helminth infracommunities occurred only irregularly and occasionally. This agrees with the typical pattern of helminth infection in many reptiles, i.e., few species occur frequently, few species occur with moderate prevalence, and many species are rare (Roca and Hornero, 1994).
Gallotia caesaris caesaris and G. c. gomerae have diversity patterns of intestinal helminth infracommunities (Table IV) that are similar to those of other insular saurians. Thus, Podarcis pityusensis and $P$. lilfordi, both from the Balearic Islands (western Mediterranean), show values of Brillouin's diversity index of $\overline{\mathrm{x}} \mathrm{H}=0.242$, range $0-1.211$ and $\overline{\mathrm{x}} \mathrm{H}=0.108$, range $0-0.815$, respectively (Roca and Hornero, 1994). Gallotia galloti galloti from Tenerife Island, shows values of $\bar{x} H=0.160$, range $0-$ 0.94 (V. Roca, unpubl.). Such low diversity values agree with values observed in most reptiles (Aho, 1990) and suggest that the helminth infracommunities of G. c. caesaris and G. c. gomerae are depauperate and isolationist, a pattern probably widespread among lizards. Some characteristics of the reptile hosts, i.e., ectothermy, simplicity of the alimentary canal, and low vagility (Kennedy et al., 1986; Roca and Hornero, 1994), may be responsible for this pattern.

The total number of helminth species in the populations of G. c. caesaris and G. c. gomerae greatly exceeded both the average and the maximum number of species per individual lizard; thus, no single infracommunity included all species locally available. This upper limit on species richness is not usually realized (Poulin, 1998). This agrees with the results obtained for Gallotia galloti (V. Roca, unpubl.) and seems to be a pattern typical of many lacertid lizards (Roca and Hornero, 1994; Roca, 1999).

TABLE III. Comparison of the prevalences of different species of lacertid lizards from the Iberian Peninsula and several Mediterranean islands, and the hosts from La Gomera and El Hierro. Source of data of Mediterranean hosts is from Roca (1995).

\begin{tabular}{lll}
\hline & \multicolumn{1}{c}{ Locality } & Prevalence $(\%)$ \\
\hline Canarian insular hosts & & \\
$\quad$ Gallotia caesaris caesaris & El Hierro (Spain) & 85.2 \\
G. c. gomerae & La Gomera (Spain) & 81.0 \\
Mediterranean insular hosts & & 79.4 \\
$P$ Podarcis pityusensis & Ibiza-Formentera (Spain) & 72.2 \\
$P$. litfordi & Mallorca-Menorca islets (Spain) & 65.8 \\
$P$. muralis & Rioux archipelago (France) & 62.3 \\
$P$. sicula & Corsica (France) & 71.4 \\
$P$. milensis & Milos (Greece) & 73.1 \\
$P$. erhardii & Lesvos (Greece) & \\
Mediterranean continental hosts & & 66.1 \\
$P$. hispanica & Iberian Peninsula & 45.7 \\
$P$. muralis & Iberian Peninsula & 66.1 \\
L. bocagei & Iberian Peninsula & 53.5 \\
\hline
\end{tabular}


TABLE IV. Overall diversity parameters of helminth infracommunities from both hosts.

\begin{tabular}{|c|c|c|c|c|c|}
\hline Host & $\mathrm{n}$ & $\begin{array}{l}\text { Species } \\
\text { richness* }\end{array}$ & $\begin{array}{l}\text { Helminth } \\
\text { abundance* }\end{array}$ & Diversity* & $\begin{array}{c}\text { Proportion of sample } \\
\text { with } 0 \text { or } 1 \\
\text { helminth species }\end{array}$ \\
\hline G. c. gomerae & 21 & $1.4 \pm 1.0(0-3)$ & $52.6 \pm 84.2(0-326)$ & $0.3 \pm 0.4(0-1.0)$ & 0.6 \\
\hline
\end{tabular}

* Values are given as the mean $\pm \mathrm{SD}$, with the range in parentheses.

\section{ACKNOWLEDGMENTS}

We thank those who helped us with fieldwork in the Canary Islands: Gustavo Llorente, Albert Montori, Nuria Orrit, Silvia Lope, and Xavier Santos (University of Barcelona, Spain), Miguel Angel Carretero (CIBIO, Portugal); also people who helped us in the laboratory: José V. Sánchez-Mut, Joana Muniesa, and $\mathrm{M}^{\mathrm{a}}$ Angeles Galdón (University of Valencia, Spain); and also Enrique Font (University of Valencia) who reviewed the English. This study was financed by Project PB98-1450 of the DGCYT (Spain). Permits (04/07/JVJ/JLRL and 04/07/TAB/JLR) for collecting living specimens were granted by the Viceconsejería de Medio Ambiente of the Canarian Government.

\section{LITERATURE CITED}

Aно, J. M. 1990. Helminth communities of amphibians and reptiles: Comparative approaches to understanding patterns and processes. In Parasite communities: Patterns and processes, G. Esch, A. Bush, and J. Aho (eds.). Chapman and Hall, London, U.K., p. 157-195.

ARNOLD, E. N. 1973. Relationships of Palaearctic lizards assigned to the genera Lacerta, Algyroides and Psammodromus (Reptilia, Lacertidae). Bulletin of the British Museum of Natural History (Zoology) 25: 289-366.

Barahona, F., S. E. Evans, J. A. Mateo, M. García-Márquez, and L. F. LÓPEZ-JURADO. 2000. Endemism, gigantism and extinction in island lizards: The genus Gallotia on the Canary Islands. Journal of Zoology 250: 373-388.

Bush, A. O., K. D. Laferty, J. M. Loft, and A. W. Shostak. 1997. Parasitology meets ecology on its own terms: Margolis et al. revisited. Journal of Parasitology 83: 575-583.

Dobson, A. P., AND S. W. PaCala. 1992. The parasites of Anolis lizards in the northern Lesser Antilles. II. The structure of the parasite community. Oecologia 92: 118-125.

J. D. Rougharden, E. R. CARPer, and E. A. Harris. 1992. The parasites of Anolis lizards in the northern Lesser Antilles. I. Patterns of distribution and abundance. Oecologia 91: 110117.

EDwARDS, D. D., AND A. O. Bush. 1989. Helminth communities in avocets: Importance of compound community. Journal of Parasitology 98: 439-445.

García-Márquez, M., A. Caetano, I. Bello, L. F. López-Jurado, and J. A. Mateo. 1999. Ecología del gato cimarrón en el ecosistema termófilo de El Hierro (Islas Canarias) y su impacto sobre el lagarto gigante (Gallotia simonyi). In El lagarto gigante de El Hierro: Bases para su conservación, L. F. López-Jurado, and J. A. Mateo (eds.). AHE, Monografías de Herpetología 4: 207-222.

, L. F. LóPeZ-Jurado, AND J. A. MATeO. 1999. Características reproductoras y procesos demográficos en una población de Gallotia caesaris (Lacertidae) de El Hierro (Islas Canarias). In El lagarto gigante de El Hierro: Bases para su conservación, L. F. López-Jurado, and J. A. Mateo (eds.). AHE, Monografías de Herpetología 4: 223-239.

GoldberG, S. R., AND C. R. BuRSEy. 1998. Composition of helminth communities in montane and lowland populations of the western fence lizard, Sceloporus occidentalis from Los Angeles county, California. American Midland Naturalist 140: 186-191.

- AND H. CHEAM. 1996. Gastrointestinal helminths of six Anole species, Anolis armouri, A. barahonae, A. bahorucoensis, A. brevirostris, A. chlorocyanus and A. coelestinus (Polychrotidae) from Hispaniola. Caribbean Journal of Science 32: 112-115.

,, AND 1 1999. Composition of the helminth com- munity of a montane population of the side-blotched lizard, Uta stansburiana (Phryonosomatidae) from Los Angeles county, California. American Midland Naturalist 141: 204-208.

Hornero, M. J., AND V. RocA. 1992. Helmintofauna de Podarcis lilfordi (Günther, 1874) (Sauria, Lacertidae) de los islotes de Menorca (Islas Baleares, Mediterráneo Occidental). Miscelània Zoològica 16: $1-6$.

Kennedy, C. R., A. O. Bush, And J. M. Aho. 1986. Patterns in helminth communities: Why are birds and fish different? Parasitology 93: 205-215.

MAgURRAn, A. E. 1988. Ecological diversity and its measurement. Crom. Helm. Ltd., London, U.K., 179 p.

MANKAU, S. K., AND E. A. WidMER. 1977. Prevalence of Mesocestoides (Eucestoda: Mesocestoididea) tetrathyridia in southern California reptiles with notes on the pathology in the Crotalidae. Japanese Journal of Parasitology 26: 256-259.

Mas-Coma, S., J. G. Esteban, M. D. Bargues, and M. A. Valero. 1987. La evolución de una fauna parasitaria en las islas "continentales": el caso de los helmintos de micromamíferos en las Gimnésicas y Pitiusas (Archipiélago Balear). In Mamíferos y helmintos. Volumen homenaje al Prof. Dr. Dr. Herman Kahmann en su 81 aniversario, V. Sans-Coma, S. Mas-Coma, and J. Gosálbez (eds.). Ketrés, Barcelona, Spain, p. 203-216.

- AND C. Feliu. 1984. Helminth fauna from small mammals (insectivores and rodents) on the Pityusic Islands. In Biogeography and ecology of the Pityusic Islands, H. Kuhbier, J. A. Alcover, and C. Guerau d'Arellano Tur (eds.). Dr. W. Junk Publishers, The Hague, The Netherlands, p. 469-525.

Mateo, J. A., AND M. GarcíA-Márquez. 2002. Gallotia caesaris. In Atlas y Libro Rojo de los anfibios y reptiles de España, J. M. Pleguezuelos, R. Márquez, and M. Lizana (eds.). Dirección General de Conservación de la Naturaleza, Madrid, Spain, p. 200-201.

PoINAR, G. O. JR. 1983. The natural history of nematodes. Prentice Hall Inc., New Jersey, 323 p.

Poulin, R. 1998. Evolutionary ecology of parasites. Chapman and Hall, London, U.K., 212 p.

RocA, V. 1995. An approach to the knowledge of the helminth infracommunities of Mediterranean insular lizards (Podarcis spp.). In Scientia herpetologica, G. A. Llorente, A. Montori, X. Santos, and M. A. Carretero (eds.). AHE, Barcelona, Spain, p. 285-292.

. 1999. Relación entre las faunas endoparásitas de reptiles y su tipo de alimentación. Revista Española de Herpetología 13: 101121

, G. García-Adell, E. López, and L. M. Zapatero-Ramos. 1987. Algunas formas adultas y larvarias de platelmintos de reptiles de las Islas Canarias. Revista Ibérica de Parasitología 47: 263-270. - AND M. J. Hornero. 1991. Helmintofauna de Podarcis pityusensis (Boscá, 1883) (Sauria: Lacertidae). Revista Española de Herpetología 5: 77-87.

- AND 1 1994. Helminth infracommunities of Podarcis pityusensis and Podarcis lilfordi (Sauria: Lacertidae) from the Balearic Islands (western Mediterranean Basin). Canadian Journal of Zoology 72: 658-664.

, J. Lluch, AND P. NAVARRo. 1986. Contribución al conocimiento de la helmintofauna de los herpetos ibéricos. V. Parásitos de Psammodromus algirus (L., 1758) Boulenger, 1887, Psammodromus hispanicus Fitzinger, 1826 y Acanthodactylus erythrurus (Schinz, 1833) Mertens, 1925 (Reptilia: Lacertidae). Boletín de la Real Sociedad Española de Historia Natural (Biología) 81: 69-78. , J. E. Martin, AND E. CARBonell. 1999. Helminths parasitising 
endemic geckoes from Canary Islands. Miscellània Zoològica 22: 101-108.

Sanchis, V., J. M. Roig, M. A. Carretero, V. Roca, and G. A. LloRENTE. 2000. Host-parasite relationships of Zootoca vivipara (Sauria: Lacertidae) in the Pyrenees (North Spain). Folia Parasitologica 47: $118-122$.

Soldatova, A. P. 1944. A contribution to the study of the development cycle in the cestode Mesocestoides linneatus (Goeze, 1872) parasitic of carnivorous mammals. C. R. Doklady Akademy Science USSR 45: 310-312.

Solera-Puertas, M. A., P. Astasio-Arbiza, L. M. Zapatero-Ramos, And C. CASTAÑo-Fernández. 1988. Descripción de Thelandros ti- nerfensis $\mathrm{n}$. sp. (Nematoda, Pharyngodonidae) sobre Chalcides viridanus Boulenger, 1887 y Gallotia galloti galloti Duméril y Bibron, 1839, de la isla de Tenerife (Islas Canarias). Revista Ibérica de Parasitología 48: 33-39.

Thorpe, R. S., D. P. McGregor, And A. M. Cumming. 1993. Molecular phylogeny of the Canary Island lacertids (Gallotia): Mitochondrial DNA restriction fragment divergence in relation to sequence divergence and geological time. Journal of Evolutionary Biology 6: $725-735$.

Voge, M. 1955. North American cestodes of the genus Mesocestoides. University of California Publications of Zoology 59: 125-156.

YAMAGUTI, S. 1963. Systema helminthum. V. Acanthocephala. Interscience Publishers Incorporated, New York, $421 \mathrm{p}$. 